Volume 3, No. 3, September - December 2018 ISSN: 2503-4235 (p); 2503-4243 (e)

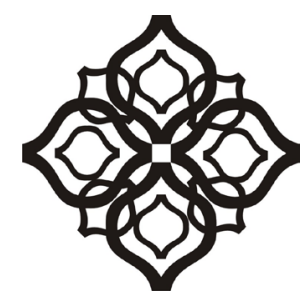

Shirkah

Journal of Economics and Business 


\section{Shirkah}

Journal of Economics and Business

Vol. 3, No. 3, September-December 2018

ISSN: 2503-4235 (p); 2503-4243 (e)

\section{Editor in Chief}

Dwi Condro Triono

\section{Managing Editor}

Jasanta Peranginangin

\section{Editorial Boards}

Abdul Azim Islahi,

Islamic Economics Institute, King Abdulaziz University, Saudi Arabia

Abu Umar Faruq Ahmad,

UBD School of Business and Economics Universiti, Brunei Darussalam

Cedomir Nestorovic,

ESSEC Business School Asia Pacific, Singapore

Fitri Wulandari,

Faculty of Islamic Economics and Business, IAIN Surakarta, Indonesia Johan Fischer,

Department of Social Sciences and Business Roskilde Universitetscenter, Denmark Muhamed Zulkhibri,

Islamic Research and Training Institute, Islamic Development Bank, Saudi Arabia M. Kabir Hassan,

Department of Economics and Finance, University of New Orleans, United States Musa Asy'arie,

Faculty of Islamic Economics and Business, IAIN Surakarta, Indonesia Nunung Nurul Hidayah,

Aston Business School, Aston University, Birmingham, United Kingdom

Saim Kayadibi,

Department of Economics, Kulliyyah of Economics and Management Science, International Islamic University Malaysia, Malaysia 
Shaikh M Ghazanfar,

Departement of Economics, University of Idaho, Russian Federation

Sigit S. Wibowo,

Department of Management, Faculty of Economics and Business, Universitas Indonesia, Indonesia

Vihang R. Errunza,

Desmarais Global Finance Research Centre, Desautels Faculty and Management, McGill University, Canada

\section{Assistant to Editor}

M. Endy Saputro

M. Zainal Anwar

Shirkah Journal of Economics and Business is a peer-reviewed journal published three times a year (January-April, May-August and September-December) by Faculty of Islamic Economics and Business, Institut Agama Islam Negeri (IAIN) Surakarta Central Java, Indonesia. The main objective of Shirkah is to offer an academic space of exchange ideas and initiate the increase number of qualified article produced by postgraduate students, practitioners and academicians.

\section{Editorial Office}

Ruang Jurnal Shirkah

Lantai Dasar, Sayap Barat, Fakultas Ekonomi dan Bisnis Islam, IAIN Surakarta

Jln. Pandawa No. 1, Kartasura, Sukoharjo, Jawa Tengah Kode Pos. 57168

Phone (+62271) 781516 Fax: (+62271)782336

E-mail: shirkahjournal@iainsurakarta.ac.id; shirkahiainsurakarta@gmail.com Website: http://shirkah.or.id/ 


\section{Shirkah}

\section{Journal of Economics and Business}

Vol. 3, No. 3, September-December 2018

ISSN: 2503-4235 (p); 2503-4243 (e)

\section{Table of Contents}

\section{Articles}

Addiarrahman

Ekonomi Kemakmuran Bersama

Indonesian Islamic Economic Thought of KahrudinYunus

Noviy Hasanah

Pasar Resisting Mall

A Cross-Cultural Ethnographic of Economic Traditional Market

Muslich

Implanting Religious Practices

Economic Behavior of Kemloko Tobacco Farmers

Arfah Habib Saragih

Generation XYZ's Perception on Zakat Mal

and Tax A Planned Behavior

Wenda Wahyu Christiyanto, Mardi Astutik

Integrated Marketing and Customers' Decision Saving Funds in Islamic Banks

Sri Walyoto

Carbon Costs of Indonesian Forested Land Conversion to

Oil Palm Plantations 


\title{
Pasar Resisting Mall A Cross-Cultural Ethnographic of Economic Traditional Market
}

\author{
Noviy Hasanah \\ University of Cologne, Germany and Universitas Negeri Medan \\ noviyhasanah@gmail.com
}

\begin{abstract}
Yogyakarta since the late ten years has shifted an economic direction taking impacts on such economic sectors as that of pasar (Javanese traditional market). Pasar, as a daily space for economic interaction of the society, has been threatened by the increasingly numbers of malls. This article critically tells the story of Gowok small trader resistance to the existence of a nearby mall. Doing ethnography for several months and in-depth interviews with some small traders, the author who comes from non-Javanese native have reflectively analyzed the cultural economy of the Javanese people. This article argues that market traders of pasar Gowok has transformed the pattern of buying and selling behavior and increased the variety of merchandise.
\end{abstract}

Keywords: mall, Yogyakarta, pasar, traditional market, Javanese

\section{Introduction}

As released by bisnis.com, the contribution of traditional market sales has continued to decline after the emergence of shopping malls in Indonesia. In 2002 the dominance of market was 75\%, while in the past year it has dropped to only $70 \%$. The rapid emergence of malls and modern retail is inversely proportional to the growth rate of traditional markets. About eight percent of the total 13 thousand traditional markets in Indonesia have been forced to close. Without the willingness to empower traditional markets, the next eight years all traditional markets in Indonesia are only a few (Colombijn, et al, 2005). 
This condition is of course a bad signal for the continuity of the traditional economics, especially in Yogyakarta. In fact, the function of pasar Gowok as a traditional market in Yogyakarta has powerful impact to surrounding society. Its functions include providing goods or services; while its role is to accelerate income distribution, add value to regional goods and services, and improve people's lives. Such economic activities of the people have a strategic position and potential to realize a more balanced national economic structure in general (McChesney, 2003; Sulistia, 2006).

The emergence of Ambarrukmo Plaza, as one of the new economic icons of Yogyakarta, has been captivating impacts in a decrease buying and selling activities in the pasar Gowok. How does the merchant take response these changing economic activities? This article ethnographically answers such question by participating and doing interview with some pasar Gowok traders. Three months participating within the traders, this author realizes the changing economic behavior of the traders facing the existence of the Ambarrukmo Plaza (see also Chen \& Zhong, 2017; Erkip \& Ozuduru, 2015).

\section{Shopping Malls in Ambarrukmo}

The decline of economic activities in pasar Gowok can be explained in several descriptions. Place; the Ambarrukmo Plaza has certainly been built in the arrangement of interactive design, luxurious interior and exterior decoration which attract the customer to shop, while communicating goods display make the consumer enjoying her desire to shop. Moreover, this plaza has provided a comfort food court with modern facilities, full music in every corner, and entertainment performances; this make the consumers who do window shopping feel at home for a long time. Those who dare entertainment choose Ambarrukmo Plaza as a place of recreation also. Some visitors use this mall as a lobbying space for business 
purposes and spending time with friends. Overall, the attractiveness of Ambarrukmo Plaza has ben a striking drive that can divert the flow of the customers. This condition has expressively clarified the negative impact of Ambarrukmo Plaza.

The ecofriendly design of the Ambarrukmo Plaza building has supported smooth air circulation, regular clean water sanitation and refreshing air flow. To avoid careless garbage disposal, the mall provides trash cans in every corner. In addition, the provision of toilets, without any charge payment, has been available on every floor. On the contrary, the environment of pasar Gowok is inadequate of hygiene sanitation. While shopping in the rainy season, the customers have to pass through a muddy area. The customers are charged a fee for using this toilet facility. To anticipate some criminal, the plaza provides a strictly security system; while entering the main gate the security has checked every customers. In addition, for the convenience of the customers, a central cooling airconditioning system has sprayed out throughout the rooms.

No bargain. The bargaining process between the traders and the customer has been a key feature of pasar activities (Evers \& Schrader, 1994). The price would not being a fixed price. In general, the purchase of goods begins with a question and answer price, followed by the bargaining process. These activities involve the interactive process. It takes short process of bargaining, but sometimes it takes longer process. It has been determined by the agreement of price among both. The selling price would be fixed according to such agreement. Even though there has been a process of bargaining, whether short or long, yet it drop into disagreement price both will not reach the fixed price.

The market system of Plaza Ambarrukmo has applied a fixed price. The price has not been determined by bargaining as is the case in the Gowok Market. The price of each item has listed on the outer package. 
The customers determine the bought item based on the printed price. Once the customer matches the printed price, they will take and paid the goods. By purchasing goods at this fixed price, those who have limited time can avoid the long duration of the process of bargaining. It would be a reason why the customers choose Ambarrukmo Plaza as a place to shop.

Changing price; the price of goods is a matter of convention. It can go up and go down, due to several factors. First, such natural disasters as floods, earthquakes, landslides and tsunami give a great impact on the increase price. A steady increase of the price has occurred at pasar Gowok due to the 6.7 Richter scale earthquake hit Yogyakarta in May 2006. The earthquake took a great impact on a scarcity of goods because the damage of natural resources. Second, such feast days as Ramadan, Eid al-Fitr, Eid al-Adha, Christmas, and Chinese New Year also encourage high influence on the upsurge price, because the more demand for goods, the more limited stock.

In certain times, the traders of the pasar Gowok have reduced prices to the lowest ones, especially at the end of market activity. It has been applied by some vegetable vendors in order to sell vegetables out in one day. If the vendors would not grasp the target of selling, the vendors get the risk whether the vegetables come to be withering or decrease in quality. It certainly cannot be sold for the next day. Meanwhile, the sales system of Plaza Ambarrukmo has offered a discount. This moment can be found in special seasons, for example, welcoming Ramadan, Eid al-Fitr, Christmas, New Year and certain holidays. The discounts can reach up to $70 \%$. This discount attracts the customers' attention; in doing so the mall will be more crowded than usual.

Some customers choose to buy groceries at Ambarrukmo Plaza because of its offering price than that of in pasar Gowok. Due to be able to buy the groceries directly from the producer in large quantities, the plaza 
would give the lower price for the costumers also. These conditions have become reason that produces the traders of pasar Gowok to be nervous, they are helpless with this condition. Small traders have limitations in price maneuvers because they do not have a management system similar to that of Plaza Ambarrukmo.

Service; the form of service provided by the traders of pasar Gowok is to deal directly with the customers. The traders help to choose the goods. At Ambarrukmo Plaza, conversely, the customers choose their needy goods based on their own interest. For ease payment, Plaza Ambarrukmo affords a debit system of ATM cards. In addition, there is also a member card service for customers to give special discounts in certain seasons. This trick was carried out by Plaza Ambarrukmo to keep customers coming to shop. Of course this was not found by the customers when shopping at the pasar Gowok. Plaza Ambarrukmo also provides a unit of baby's room, prayer room and hygienic toilet located on each floor. For visitors who will take a short break, the plaza has a beautiful garden complete with fountains located in front of the east side of the building. In addition, to support excellent service, this plaza has also customer service (CS) that is always ready to serve both visitors and tenants.

Effective shopping; every malls put its concept into a jargon one stop shopping, where almost all daily needs are sold here. Clothing and food are available in the mall, both for children, adolescents and adults. This condition makes the customers feel to be effective and efficient because, by only visiting one shopping place, all needs can be fulfilled. Furthermore, the Ambarrukmo Plaza has been indeed trying to complement the needy commodities. Along with the complete sale of commodities, it is also possible to find variations of the price of the same commodity. When the customers eager to buy a commodity she may adjust to her purchasing power. Those customers who have busy matters would be getting effective time to shop in one place. 
Interior design; the display of goods at Ambarrukmo Plaza is very attractive. In a certain period of time there will be unique decoration, especially in welcoming certain seasons, such as Eid, Christmas, New Year, and Chinese New Year. Of course with this dynamic atmosphere, it can further enhance the attractiveness of visitors and customers. This item display has been initially categorized by type, function and quality of goods in order to make easy buying for the customers.

Complete Items; high-quality and branded goods are sold at this plaza. The customers may find famous brands from abroad. In addition, such branding stores are also available within, as Carrefour, Centro, Gramedia, Timezone, Cineplex 21, Tamansari Food Court, and Caesar Lounge \& Café. These stores afford all the needs of families, parents and children ranging from monthly shopping necessities, clothing, entertainment, books, salons, body care to food. No wonder when the customers come to Plaza Ambarrukmo, she can fulfill all needs at one place simultaneously. Considering the better facilities of plaza Ambarrukmo, the customers of course would likely choose to shop in the plaza rather than in the pasar. This fact is somehow in line with Goldsmith's statement that each individual fights for a wider space for expression and decision making (Aburdene, 2006).

\section{Modes of Resistance}

As previously describe, there was a decrease of economic activities in pasar Gowok after the presence of Plaza Ambarrukmo. To survive from the attractiveness of the plaza, the traders of pasar Gowok Market have made a "resistance" strategy. Increase the amount of capital; to get around the market changes, the traders of pasar Gowok are currently performing a strategy to maintain their customers. Sugiyem (51 years) and Muhasti (51 years), a kitchen tools trader in pasar Gowok who has been selling for 
13 years, have her own way of increasing the amount of her merchandise capital. Sugiyem got a loan from her sister, while Muhasti made her arisan to increase trading capital, in doing so the commodities would become more complete. This would be a soft resistance to globalization that has become a great domination which demands a fast response (Ratih \& Faturochman, 2000; Smith, 2001; Abdullah, 2006). The traders act to increase the economic capital in order to complement their commodities. Thus they can also sell those commodities in many variants. Hopefully, it is expected that the customers would have better shopping choices, both in quality and quantity.

Extending sales period; the traders of pasar Gowok have extended their working hours. This strategy is quite effective considering that traditional markets are usually known to have short sales periods (Muntiyah $\&$ Sukamdi, 1997). If the customers have time to shop after office hours, they will be disappointed when he comes to pasar Gowok, due to the traders still open their service. Muhasti (51 years) confirmed, by extending the sales period, she could get more profit than usual. This strategy is carried out to balance the Ambarrukmo Plaza which has a sales period that is longer than the pasar Gowok.

Improving service; the traders have performed their service depends on what commodities they sell. Sri Astuti (42 years) provides extra services for cleaning, peeling and slicing vegetables and fruit she sells. Adding diverse commodities; the next mode of resistance is to increase their trade numbers and variety of commodities. Increasing the diversity of trade commodities will make the image of pasar Gowok as one of the complete traditional markets. For this reason, the traders are demanded to be more careful and responsive to the emergence of new commodity variants. The traders get information from their suppliers, from news on television, or directly through the costumers (Aliyah, Setioko, \& Pradoto, 2017; Kimbal, 2015; Lee, Kim, \& Kim, 2018). 
Increasing display of commodities; it is understandable that neat display of merchandise has a correlation with the customer's interest. The customers have naturally enjoyed something beautiful and pleasing to the eye. Albeit selling it traditionally, the pasar display must be added value offered to the customers. The customers still have choice to shop and been notified if there is a new item. It is an interactivity that not being available that of in Plaza Ambarrukmo. Implementing these strategies, it is expected that the traders of pasar Gowok will be able to deal with the market changes.

Some economic anthropologists have long been studying pasar as one of the economic institutions that take an important economic role within the cultural context of Javanese society (Abdullah, 1991; Abdullah, 1994; Abdullah, 1999) Arguably, it is a close relationship between culture and market activity (Masinambow, 1997). Dealing with this argument, pasar in Java certainly also have that of relations. Pasar in Java has become an important social institution that is not being a place to supply goods for consumption only, but as being a center of interaction also. As a place to shop, pasar offers the daily needs of the local society (Ngatidjo, 2001). As a center of interaction, pasar provides space for the customers to be able to communicate interactively with some traders, beginning with bargain activities and continuing with a close relationship.

Pasar or peken located in strategic place, while surrounding people can easily go to the pasar. Pasar in a certain area of Java only have trading activities once a week based on pasaran (old Javanese days). Pasar has been inherently embedded in Javanese society; how crowd pasar within certain Javanese day (pasaran) shows that pasar initially invites surrounding people to come to this place as a cultural event (Subandi, 2005). Each pasar has culturally called by Javanese days, such as legi, pahing, pon, wage and kliwon. In addition, there are several markets that take the name of the 
place is located. Such markets usually grow at crossroads close to residential housing of a society (Koentjaraningrat, 1994; Mangkara, Hasibuan, \& Chairani, 2018). Pasar located in the city has been occupied by a number of traders who sell the same type of goods and that of services. These traders have settled permanently. However, there are also some traders who hold their wares on the edge of the market. These traders come and go (unsettled), while they arrive late they move to another location.

The main character of pasar in Javanese society put in the negotiation of prices. For this reason, pasar has socio-cultural functions other than economics. Due to this negotiation, prices of commodities are not fixed; the bargaining process that occurs has also adjusted to the quality of goods at that time (Abdullah, 1990). Both the traders and the customers, they usually understand well the market conditions of certain goods (Koentjaraningrat, 1994; Naisbitt \& P. Aburdene, 1990). Although traders usually determine the price of their goods for themselves, however their behaviors rather take effects on the stable price of goods. One to another trader will not increase the price of being determined by other prices. As a result of bargaining, differences in the negotiated price commodities may occur, yet it is not so influential matters. Using the bargaining process, pasar would not be a place for economic activities only, but as a place for social interaction. This interaction can continue to be a friend or relative relationship. It is known as tuno sathak, bathi sanak, although it loses a little, yet you get relatives. This cultural pattern shows how important the socio-cultural dimension within pasar economic activities (compare to Mangkara, Hasibuan, \& Chairani, 2018). 


\section{Conclusion}

The market has resisted the emergence of the plaza Ambarrukmo. Responding to the easy shopping facilities provided by the plaza Ambarrukmo, the pasar traders have practiced act of resistance to these conveniences. The pasar traders have an effort to increase business capital in order to enrich the type of merchandise. They work and stay in pasar longer than usual. They also tried to beautify the displays of goods. The service has also been improved, in doing so the consumers continue to be permanent customers. Service has its own advantages in the context of the pasar Gowok. The concept of tuna sathak bathi sanak is an economic cultural concept to keep the economic activities of the pasar using the principle of bargaining. Although the resistance of market traders cannot compare to such various facilities in the Ambarrukmo Plaza, however the pasar traders have tried to respond to changes in the economic community.

During the research at pasar Gowok, certainly close relationship can be established with some informants. The author do interview to such traders on the spinoffs of their busy life while serving the customers, between breakfast hours, even their lunch hours. They sometimes introduce me to some of their customers who were shopping. I always want to know more about them and about the market. The pasar traders (as being informants) have to have curiosity about me as someone they just knew. They sometimes ask about my hometown or some food in my city. As best I can, I have explained briefly but enthusiastically to them.

In the beginning of doing research, I tried to study "working hours" and their facial expressions when communicating goes on. While their faces are enthusiastic about the topic I will continue to asking. However, if my question somewhat makes them reluctant to explain further, then I will try as much as I can to get them interested in. Another approach that I did was to anticipate their working hours. I chose to ask on the time out 
of their busy life; yet most important I had to be sure first that they were agree with the timing. After doing research, it would be possible changing concept of "tuno sathak, bathi anak", losing profit gaining daughter. 


\section{References}

Abdullah, I. (1990). "Wanita ke Pasar: Perubahan Sosial Ekonomi Pedesaan Jawa.” Populasi, 1(1).

Abdullah, I. (1991). Wanita Bakul di Pedesaan Jawa. Yogyakarta: Pusat Penelitian Kependudukan Universitas Gadjah Mada.

Abdullah, I. (1994). The Muslim Businessmen of Jatinom - Religious Reform and Economic Modernization in a Central Javanese town. Amsterdam: Universiteit Van Amsterdam.

Abdullah, I. (1999). "Krisis Ekonomi, Daya Tahan Penduduk, dan Social Security : Kasus Jatinom di Jawa Tengah.” Populasi, 10(1).

Abdullah, I. (2006). Konstruksi dan Reproduksi Kebudayaan. Yogyakarta: Pustaka Pelajar.

Aburdene, P. (2006). Megatrends 2010 - Bangkitnya Kesadaran Kapitalisme - Tujuh Trend Baru yang Akan Mengubah Strategi Kerja, Investasi, dan Gaya Hidup Anda. Jakarta: Trans Media.

Aliyah, I., Setioko, B., \& Pradoto, W. (2017). Spatial flexibility in cultural mapping of traditional market area in Surakarta (A case study of Pasar Gede in Surakarta). City, Culture and Society, 10, 41-51. https://doi. org/10.1016/j.ccs.2017.05.004

Chen, D., \& Zhong, M. (2017). Design and material selection of shopping malls point-of-purchase displays (Vol. 417). https://doi. org/10.1007/978-981-10-3530-2_86

Colombijn, et al, F. (eds). (2005). Kota Lama, Kota Baru: Sejarah Kota-kota di Indonesia Sebelum dan Setelah Kemerdekaan. Yogyakarta: Ombak.

Erkip, F., \& Ozuduru, B. H. (2015). Retail development in Turkey: An account after two decades of shopping malls in the urban scene. Progress in Planning, 102, 1-33. https://doi.org/10.1016/j. progress.2014.07.001 
Evers, H.-D., \& Schrader, H. (Editor). (1994). The Moral Economy of Trade Ethnicity and Developing Markets. London: Routledge.

Kimbal, R. W. (2015). The design of ideal social capital for the development of traditional market in the mix-barter transaction in pasar blante kawangkoan. International Journal of Applied Business and Economic Research, 13(7), 5703-5720.

Koentjaraningrat. (1994). Kebudayaan Jawa (Seri Etnografi Indonesia). Jakarta: Balai Pustaka.

Lee, C.-S., Kim, Y.-K., \& Kim, S.-H. (2018). A study on retail competition structure in traditional market. Journal of Distribution Science, 16(6), 55-63. https://doi.org/10.15722/JDS.16.6.201806.55

Mangkara, S. B., Hasibuan, H. S., \& Chairani, E. (2018). Using life cycle inventory to improve the sustainability of traditional market management: A case study in Pandansari Market Balikpapan and Ibuh Market Payakumbuh. In E3S Web of Conferences (Vol. 74). https:// doi.org/10.1051/e3sconf/20187411001

Masinambow, E. K. . (1997). Koentjaraningrat dan Antropologi di Indonesia. Jakarta: Yayasan Obor Indonesia.

McChesney, A. (2003). Memajukan dan Membela Hak-hak Ekonomi, Sosial, dan Budaya. Yogyakarta: Insist Press.

Muntiyah, \& Sukamdi. (1997). "Strategi Kelangsungan Hidup Rumah Tangga Miskin di Pedesaan.” Populasi, 8(2).

Naisbitt, J., \& P. Aburdene. (1990). Megatrends 2000 - Sepuluh Arah Baru Untuk Tahun 1990-an. Jakarta: Binarupa Aksara.

Ngatidjo. (2001). Kapasitas Ekonomi Lokal - Studi Penjajagan Penguatan Ekonomi Lokal dengan Community Currencies System - Gunungkidul. Yogyakarta: Puskopdit.

Ratih, D., \& Faturochman. (2000). "Strategi Bertahan Hidup di Tiga Wilayah”. Populasi. Populasi, 11(1).

Smith, P. (2001). Cultural Theory - An Introduction. Australia: Blackwell Publishing. 
$320 \quad$ Noviy Hasanah

Subandi, I. (2005). Lifestyle Ecstasy: Kebudayaan Pop dalam Masyarakat Komunitas Indonesia. Yogyakarta: Jalasutra.

Sulistia, T. (2006). Aspek Hukum - Usaha Kecil dalam Ekonomi Kerakyatan. Padang: Andalas University Press. 


\section{Shirkah Author Guidelines}

Shirkah currently offers two routes to submit manuscripts. We highly recommend to submit the articles which are made using OJS (Open Journal System). Feel free register as author soon through visiting http:// shirkah.or.id/index.php/home/user/register. The authors may directly send their manuscripts, along with their resume, to shirkahiainsurakarta@ gmail.com. Please prepare your manuscripts, using following guidelines:

1. Manuscript must be written in English. Submitted articles should not have been published or be under review for publication with another journal.

2. Manuscript's length is about $15-20$ pages, typed in one-half spaced on A4-paper size.

3. Manuscript must include an $150-200$ word abstract and keywords.

4. Manuscript must be arranged as follows: Title, Name of Author, E-mail address, Abstract, Keywords, Introduction (including method if any), Discussion, Conclusion, References.

5. Manuscript's titles not more than ten words.

6. Manuscript must be submitted in Microsoft Word or RTF.

7. Arabic words should be transliterated according to the style of International Journal of Middle Eastern Studies.

8. Manuscript references are preferably derived from the up-to-date references.

9. The author's resume should be submitted separately, consisting of at least full name, institutional address, phone number, areas of studies, and recent publications (if any).

10. Shirkab use APA Style 6th edition (2010) as reference format writing. We suggest the use of a reference manager software such as Mendeley, Zotero, and Endnote at templating the citation style. APA Style to be used is as follows: 


\section{Book with single author}

Swann, G. M. Peter. (2014). The Economics of Innovation an Introduction. Cheltenhum \& Northampton: Edward Elgar.

in-text citation: (Swann, 2014)

\section{Articles in reference books}

Alatas, S. F. (2006). Islam and the Science of Economics in Abu Rabi', I.M. The Blackwell Companion to Contemporary Islamic Thought. USA: Willey-Blackwell (pp. 587-606).

in text citation: (Alatas, 2006)

\section{E-Book}

Hackett, Rosalind (2007). "Religous Dimentions of War and Peace: Introduction." Dalam Gerrie ter Haar dan Yoshio Tsuruoka (Ed.), Religion and Society: An Agenda for the 21st Century (h. 3-6). Retrieved from http:// brill.nl.

in text citation: (Hackett, 2006)

\section{Master's thesis, from a commercial database}

McNieI, D. S. (2006). Meaning through narrative: A personal narrative discussing growing up with an alcoholic mother (Master's thesis). Available from ProQuest Dissertations and Theses database. (UMI No. 1434728)

in text citation: (Mc Niel, 2006)

\section{Doctoral dissertation, from an institutional database}

Adams, R. J. (1973). Building a foundation for evaluation of instruction in higher education and continuing education (Doctoral dissertation). Retrieved from http://www.ohiolink.edu/etd/

in text citation: (Adams, 1973) 


\section{Doctoral dissertation, from the web}

Bruckman, A. (1997). MOOSE Crossing: Construction, community, and learning in a networked virtual world for kids (Doctoral dissertation, Massachusetts Institute of Technology). Retrieved from http:/www-static. cc.gatech.edu/--asb/thesis/

in text citation: (Bruckman, 1997)

\section{Journal article with No DOI}

Bourkhis, K., and Nabi, M. S. (2013). Islamic and conventional banks' soundness during the 2007-2008 financial crisis. Journal Metrics, 22(2), 68-77.

in-text citation: (Bourkhis \& Nabi, 2013).

\section{Journal article with DOI}

Ichwan, M. (2012). The Local Politics Of Orthodoxy: The Majelis Ulama Indonesia in the Post-New Order Banten. Journal Of Indonesian Islam, 6(1), 166-194. doi:http://dx.doi.org/10.15642/JIIS.2012.6.1.166-194

In text citation : (Ichwan, 2012)

\section{Abstract as citation}

Hasan, N. (2012). Islamist Party, Electoral Politics And Da'wah Mobilization Among Youth : The Prosperous Justice Party (PKS) in Indonesia. Journal of Indonesian Islam, 6(1), 17-47. Abstract from http:// jiis.uinsby.ac.id/index.php/jiis/article/view/97

in text citation : (Hasan, 2012)

\section{Mass media article}

Sahal, Akhmad (2014, March 2). Kiai Sahal dan Realisme Fikih.Tempo Magazine, p. 120.

in text citation : (Sahal, 2014) 


\section{Research report}

Fisher, B. S., Cullen, F. T., \& Turner, M. G. (2000). The Sexual Victimization of College Women. Research Report.

in text citation : (Fisher, Cullen, Turner, 2000)

\section{Monograph}

Routray, Bibhu Prasad (2013), National Security Decision-Making in India (RSIS Monograph No. 27). Singapura: Rajaratnam School of International Studies.

in text citation : (Routray, 2013)

\section{Proceeding article}

Sudibyakto, Hizbaron, D.R., \& Jati, R (Ed.) (2009), Proceeding International Seminar Disaster Theory, Research and Policy. International seminar held by Sekolah Pascasarjana, Universitas Gajahmada, Yogyakarta, 8-9 Desember 2009.

in text citation : (sudibyakto and Jati, 2009)

\section{Paper conference/seminar/symposium}

Janutama, Herman Sinung (2011). "Kraton dan Hubungan Antar Agama." Paper presented in Seminar Kraton dan Panatagama held by Center for the Study of Islam and Social Transformation (CISForm), Yogyakarta, 17 November.

$$
\text { in text citation :(Janutama, 2011) }
$$

\section{Online article in web}

Shiva, (2006, February). Bioethics: A Third World Issue. Native-web. Diperoleh dari http://www.nativeweb.org/ pages/legal/shiva.html 


\section{in text citation : (Shiva, 2006)}

\section{Online research report}

Kessy, S. S. A., \& Urio, F M. (2006). The contribution of microfinance institutions to poverty reduction in Tanzania (Research Report No. 06.3). Retrieved from Research on Poverty Alleviation website: http://www. repoa.or.tz /documents_storage/Publications/Reports/06.3_Kessy_and_ Urio.pcif

in text citation : (kessy and urion, 2006)

\section{Holy book}

Qur an, $2(25)$

In text citation : (Q. al-Baqarah 2:25).

\section{Encyclopaedia}

Graycar, Adam (1992). Social Welfare Policy. Dalam Mary Hawkesworth dan Maurice Kogan (Ed.), Encyclopedia of Government and Politics (Vol. 1). London: Routledge.

in text citation : (Graycar, 1992)

\section{Interview}

Sultan Hamengkubuwono X (interview, 2011, April 19)

in text citation : (Hamengkubuwono, 2011)

\section{Documentary film}

Steijlen, Fridus (2008). A Day in the Life of Indonesia [documentary film, 58 minutes]. Leiden: KITLV Press.

in text citation : (Steijlen, 2008) 
Vol. 3 No. 3, September - December 2018 